\title{
Novel coronavirus pneumonia based on the DingTalk platform teaching method in the teaching of Pathogenic Biology
}

\author{
Bo Song ${ }^{1, *}$, Yan Sun ${ }^{1}$, Junjie $\mathrm{Guo}^{1}$, Dan Zhao ${ }^{1}$, and Jiayin Tan ${ }^{1}$ \\ ${ }^{1}$ Department of clinical etiology, Collede of medical technology, Qiqihar Medical University, Heilongjiang, 161000
}

\begin{abstract}
Objective: To evaluate the teaching method based DingTalk combined PBL teaching method and CBL teaching method in the teaching of pathogenic biology under novel coronavirus pneumonia enviroment. Methods: 48 undergraduates of grade 2018 were selected as the experimental group, and 48 undergraduates of grade 2017 were selected as the control group. After class, the theory test and microbiological test knowledge test and questionnaire were as the assessment index. Results: the scores of mastering microbial inspection knowledge and satisfaction in the experimental group were significantly higher than those in the control group, and the difference was statistically significant $(\mathrm{P}<0.05)$. Conclusion: compared with the traditional teaching method, PBL + CBL teaching method based on DingTalk platform is more popular with students, which can mobilize their learning initiative and improve their ability.
\end{abstract}

\section{Introduction}

Traditional teaching methods need fixed multimedia equipment, teaching places and other environmental conditions, restricted by time and place. The amount of knowledge information mainly comes from teachers' lectures and book knowledge. The form and content of teaching are relatively single, which is not conducive to teaching students in accordance with their aptitude and meeting the needs of students' personalized development[1]. Especially under some irresistible factors, traditional teaching is difficult to implement. For many years, the application of network teaching platform in the teaching of full-time college students has been in the exploratory stage.

Since the outbreak of New Coronavirus pneumonia in 2020 , the primary schools in various places have had to postpone the opening time[2] due to the epidemic prevention and control needs. In response to the impact of the epidemic on the teaching order in universities, The Ministry of Education issued the guidance on the organization and management of online teaching in Colleges and universities during the period of epidemic prevention and control[3]. Online courses are carried out all over the country, that is to take the learning management system as the carrier, digitize the traditional teaching content and teaching process, and carry out the online teaching and learning process using the network platform. How to do well job of online teaching during the period of epidemic prevention and control that is a common challenge for all teachers and students in Colleges and universities to promote "class suspension"[4]. Dingtalk is an emerging platform for team work and free communication created by Alibaba
Group[5]. It has many technical advantages, such as intelligent form filling, log, self clocking, AI translation, live broadcast, video conference, group check-in and so on. It supports the mutual transmission of files between mobile phones and computers. As an online teaching platform, dingtalk is very popular with teachers and students. Dingtalk has changed the classroom teaching mode and promoted the development of teaching Teaching reform. Students can learn anytime and anywhere, breaking through the limitations of the regional curriculum sharing system in time and space.It has achieved well results in practical application, and is widely used in Colleges and universities[6].

Case based learning (CBL) and problem-based learning $(\mathrm{PBL})$ have been gradually recognized by the majority of educators. They have been gradually developed and matured in medical education in China, and have played a role in promoting the reform and development of university teaching. Its core is the group discussion teaching method of "case-based, problem-based, student-centered and teacher led". Through case study, study and discussion, we can mobilize students' learning enthusiasm and improve their ability to find, solve and analyze problems[7]. In this paper, Since the outbreak of novel coronavirus pneumonia the teaching methods based on DingTalk platform combined with PBL and CBL teaching methods and offline PBL and CBL have been compared. To explore the advantages of COVID-19 based on the DingTalk platform teaching method compared with the traditional teaching method, in order to find a better online teaching method to serve teaching.

\footnotetext{
* Corresponding author: songbo@qmu.edu.cn
} 


\section{Object}

\subsection{Research object}

The undergraduates of grade 2018 who participated in online teaching of pathogenic biology from September 2020 to December 2020 were selected as the experimental group, and the undergraduates of grade 2017 who participated in offline teaching of pathogenic biology in the same period of time in 2019 were selected as the control group.

\subsection{Teaching materials and teaching contents}

The second edition of pathogenic biology was used in the textbook. The content of the course is hepatitis virus, the length of the course is 2 class hours, each class hour is 40 minutes, and the teachers are the same.

\section{Teaching methods}

\subsection{Experience group}

\subsubsection{Prepare before class}

Teacher preparation: DingTalk group was established by teachers, and its members included experimental group students and teachers. According to the teaching purpose and requirements, teachers select typical cases, consult literature, prepare related questions, and give guidance teachers for reference. StudentS preparation: select two students representatives, one as the host, responsible for organizing students to speak in the group, the other as a recorder, responsible for the whole process of recording. Through Wanfang, CNKI and other platforms, students can search for literature or borrow relevant teaching materials from the library to collect relevant materials, sort out and summarize the problems raised by teachers, and make sufficient preparations.

\subsubsection{Teaching process}

First of all, before the formal discussion, the classic cases were sent to the group, and the teachers raised questions, including the microbiological test methods that can be selected through clinical manifestations, the preferred microbiological test, the positive indicators of Microbiology of the disease, the diagnostic basis and the diagnosis and differential diagnosis were listed. The online case discussion on the DingTalk platform was carried out in the specified period, and the questions were put forward by the teachers During the discussion, teachers can timely ask, guide and answer questions and correct students' wrong concepts timely and signs in the interpretation of cases, put forward the basis of diagnosis and differential diagnosis, and finally give the diagnosis results. Finally, teachers can focus on the explanation according to the content of students' discussion, and give suggestions Answer the questions raised by the students and assign the related questions as homework.

\subsection{Control group}

2017 undergraduate students in the same period of 2019 academic year were selected as the control group. The control group was given offline PBL + CBL teaching mode, and the teaching courseware and case materials were the same as the experimental group.

\subsection{Teaching evaluation}

At the end of the course, the experimental group was tested. The difficulty level of the test questions was the same as that of the control group. The score of roll surface is 100. At the same time, each student will also be evaluated for satisfaction mainly in the form of questionnaire for teaching mode, method, content and other aspects of the problem, the full score of 100, the higher the score, the higher the satisfaction.

\subsection{Statistical methods}

The experimental data of this study were analyzed by spss22.0 statistical software, the measurement data were $(\mathrm{x} \pm \mathrm{s}), \mathrm{t}$ test and chi square test, $\mathrm{P}<0.05$, with statistical significance.

\section{Result}

\subsection{Comparison of satisfaction between the two groups}

The total score of online course satisfaction evaluation is 10 points, online teaching method is the experimental group, offline teaching method is the control group, the overall satisfaction of students to online course is as high as 9 points. It can be seen that students have a higher degree of acceptance of online teaching method, and the satisfaction of the experimental group is significantly higher than that of the control group, the difference is statistically significant $(\mathrm{P}<0.05)$ (Table 1$)$.

Table 1. Comparison table of satisfaction scores between the two groups

\begin{tabular}{|c|c|c|c|c|}
\hline $\begin{array}{c}\text { Number of } \\
\text { students }\end{array}$ & $\begin{array}{c}\text { experimental } \\
\text { group }\end{array}$ & $\begin{array}{c}\text { control } \\
\text { group }\end{array}$ & $\mathbf{t}$ & $\mathbf{P}$ \\
\hline 48 & $9 \pm 0.71$ & $8.46 \pm 1.18$ & 9.335 & 0.05 \\
\hline
\end{tabular}

In the whole online teaching course, the most satisfactory links for students are group discussion (35\%), PPT presentation (28\%) and inter group discussion (25\%), which shows that students prefer group discussion. 


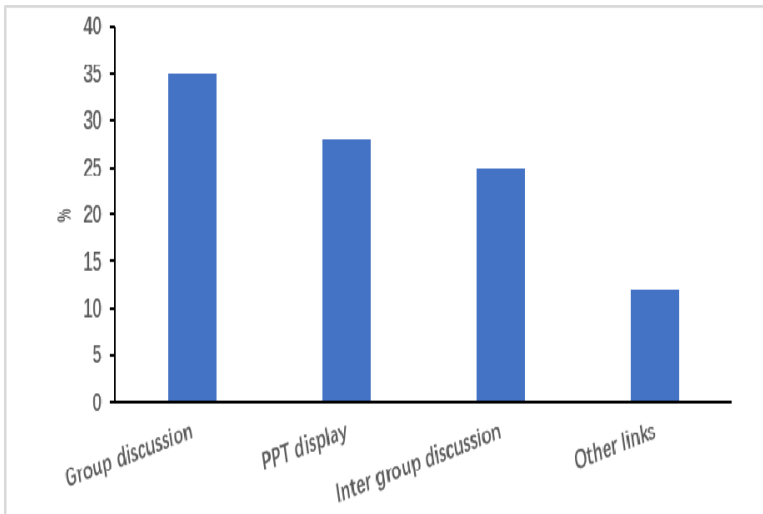

Figure 1. The most satisfactory teaching process for students

48 questionnaires were sent out and 48 were returned. Positive feedback data has been obtained in promoting learning interest, improving students' ability and facilitating students' communication and cooperation. Statistical results show that all the students think that this teaching method is better than the traditional method, but $23.96 \%$ of the students think that they rely too much on the playback function of the mobile phone, which leads to low learning efficiency (Table 2).

Table 2 questionnaire

\begin{tabular}{lc}
\hline Evaluation content $\quad$ Positive rate & $(\%)$ \\
\hline $\begin{array}{l}\text { Improve learning interest } \\
\text { The ability of consulting literature }\end{array}$ & 89.58 \\
was improved & 97.92 \\
$\begin{array}{l}\text { Improve learning ability and understanding } \\
\text { of theoretical knowledge }\end{array}$ & 95.83 \\
$\begin{array}{l}\text { Improve the ability of logical thinking } \\
\text { and clinical diagnosis and treatment }\end{array}$ & 91.67 \\
$\begin{array}{l}\text { like this kind of teaching method } \\
\text { Improve the preview willingness and the } \\
\text { ability of Integrating theory with practice }\end{array}$ & 95.83 \\
$\begin{array}{l}\text { Facilitate communication and cooperation } \\
\text { with students }\end{array}$ & 81.25 \\
$\begin{array}{l}\text { The ability of language organization } \\
\text { and communication was improved }\end{array}$ & 97.92 \\
$\begin{array}{l}\text { Over reliance on playback } \\
\text { Better than the traditional teaching method }\end{array}$ & 23.96 \\
\hline
\end{tabular}

\subsection{Examination results of the two groups}

There was no significant difference between the experimental group and the control group in the scores of theoretical course and the test results of microbiological test knowledge before class, and there was no statistical significance. After class, the scores of microbiological test knowledge in the experimental group were significantly higher than those in the control group, and the difference was statistically significant (Table 3 ).

Table 3 Comparison of results of theoretical examination and microbiological examination between the control group and the experimental group

\begin{tabular}{|l|l|l|l|l|}
\hline Project & $\begin{array}{l}\text { Experiment } \\
\text { al group }\end{array}$ & $\begin{array}{l}\text { Control } \\
\text { group }\end{array}$ & P & t \\
\hline Theoretical score \\
\hline before & $46.56 \pm 2.95$ & $44.38 \pm 5.22$ & 0.0136 & 2.528 \\
\hline
\end{tabular}

\begin{tabular}{|l|l|l|l|l|}
\hline class & & & & \\
\hline $\begin{array}{l}\text { after } \\
\text { class }\end{array}$ & $87.08 \pm 5.91$ & $85.73 \pm 6.27$ & 0.2791 & 1.089 \\
\hline $\mathrm{P}$ & 0.00 & 0.00 & & \\
\hline $\mathrm{t}$ & 42.51 & 35.10 & \\
\hline \multicolumn{5}{|l|}{ Knowledge score of microbiological examination } \\
\hline $\begin{array}{l}\text { before } \\
\text { class }\end{array}$ & $5.58 \pm 0.71$ & $5.54 \pm 0.80$ & 0.79 & 0.2704 \\
\hline $\begin{array}{l}\text { after } \\
\text { class }\end{array}$ & $8.96 \pm 0.46$ & $7.90 \pm 0.90$ & 0.00 & 6.946 \\
\hline $\mathrm{P}$ & 0.00 & 0.00 & & \\
\hline $\mathrm{t}$ & 27.66 & 13.73 & \\
\hline
\end{tabular}

\section{Discussion}

With the emergence of New Coronavirus pneumonia, various measures have been taken to restrict the flow of people throughout the country, in order to prevent the further spread of the epidemic[8]. Due to the scattered source of college students, they can not return to school on time during the epidemic period and can not attend classes normally. With the popularity of smart phones in people's lives, college students generally have smart phones[9]. In order to conscientiously implement the spirit of the document of "suspension of classes without suspension of schooling" during the epidemic period, the online class mode was opened in the teaching process.DingTalk software has a variety of functions, such as group check-in and clock out, questionnaire, homework delivery, approval, email, video or voice phone, DingTalk disk and so on. It has changed the classroom teaching mode, and can provide PC version, web version and mobile version, which not only makes students unlimited in learning time and space, but also is more easily accepted by students, and improves teaching management and teaching effect[10].

DingTalk software also has the functions of QQ, wechat, email and Internet disk. It is convenient and quick, and can be switched by one button without changing the application back and forth. It can also play a role in the daily classroom management of students. It is a mobile teaching mode to integrate theoretical knowledge with practical operation, and the class content can be watched repeatedly. We can send students' operation videos to DingTalk group for discussion and error correction, so as to mobilize students' enthusiasm and improve their learning and practical ability.

In this study, DingTalk was applied to the teaching of microbiological testing, and the influence of DingTalk platform online teaching on students' performance was discussed. This kind of teaching method enables students to strengthen their thinking and active participation before and after class. There is no need to stick to the fixed classroom and fixed time, and the classroom atmosphere is active. Teachers empower students by guiding, commenting and demonstrating, and discuss the designed problems, so that students' growth becomes the center of the curriculum. The results showed that there was no difference in the scores of theoretical knowledge between the experimental group and the control group. This shows that DingTalk online teaching and traditional offline 
teaching have little influence on students' mastery of theoretical knowledge. However, the improvement of the ability of microbiological testing knowledge is obvious, which may be related to the limitation of traditional classroom hardware equipment, so it is difficult to grasp the knowledge of microbiological testing vividly and concretely.According to the satisfaction questionnaire, the students who accept the combination of PBL and $\mathrm{Cbl}$ are more satisfied. Compared with offline classroom, the difference is statistically significant, which shows that students generally like DingTalk online teaching mode. Online teaching platform has the advantages of strong flexibility and interaction. DingTalk group also has a statistical function, which can understand the learning situation of students, such as the number of video visits, viewing time, etc., which is helpful for teachers to urge students to use mobile phones effectively and play a positive role in students' learning. In order to prevent students from not attending class in time, the deadline of homework submission can be set in the curriculum, so as to urge students to complete their homework tasks in time.

However, there are some shortcomings in the implementation of this comprehensive teaching method. Some students do not have enough preview time before class due to the intensive arrangement of online classes, the conflict of teachers' teaching time arrangement, or the inconvenience caused by network restrictions, etc., which leads to insufficient preparation before class. Because of the wide range of network resources, students are easy to contact with bad websites. Therefore, teachers should constantly adjust and give positive guidance according to students' feedback, continuously sum up experience and shortcomings, and require students to complete their homework within the specified time, so as to prevent the generation of students' inertia. In teaching, we can appropriately combine text, pictures, audio-visual and other diversified learning materials to improve students' learning enthusiasm, guide students correctly and actively, and constantly improve the teaching and education mode, so as to effectively improve the teaching level and achieve better teaching effect. Most teachers are used to the "Teacher centered" teaching method in face-to-face teaching. Teachers' understanding and application of teaching method need to be improved, and the "anxiety" brought by distance online teaching should be adjusted. Teachers should seize the opportunity in the crisis and challenge, be diligent in learning, exchange and summarize, share experience, adapt to the new era, constantly enrich their own experience, and adjust teaching methods to lay the foundation for the healthy development of school education.

\section{Acknowledgement}

Fund: 2019 Education science research project of Qiqihar Medical College QYJY20190133

\section{References}

1. Liu Zhentian, Liu Qiang. How can online teaching help college classroom revolution? -- rational cognition of large-scale online teaching action under the epidemic situation [J]. Journal of East China Normal University (EDUCATION SCIENCE EDITION), 2020,38 (07): 31-41

2. Ministry of education. Notice of Ministry of education on delaying the start of spring semester 2020 [EB / OL] http://www.moe.gov.cn/jyb_ xwfb/gzdt_gzdt/s5987/202001/t20200127_416672. html, 2020-01-27.

3. The Ministry of education of People's Republic of China. The Ministry of education should guide the office of the leading group of New Coronavirus infectious pneumonia work in conducting the organization and management of online teaching in ordinary colleges and universities during the period of epidemic prevention and control [EB/OL]. (2020-02-04) 2020-03-16]. http://www.moe.gov.cn/srcsite/A08/s7056/202002/t2 0200205_418138.html.

4. Jiao Jianli, Zhou Xiaoqing, Chen Zexuan. Case study on online teaching of "no class suspension" under the background of epidemic prevention and control [J]. China audio visual education, 2020 (03): 106-113

5. Nie Juan. Research on the application of nail in college students' mental health education under the background of epidemic situation $[\mathrm{J}]$. Chinese Journal of multimedia and network teaching (last ten days), 2020 (11): 34-36

6. Meng bin, Gao Hongsheng, Chang Liushuan, Lu Dalong. Taking the opportunity of online teaching during the epidemic period to promote the construction of "golden course" of military health $[\mathrm{J}]$. Health vocational education, 2021,39 (02): 17-19

7. Cao Xianghong, Peng Chuanmei, Wang Jia, Gao Hui, Wang Yang, Li Wenqing, Kong Fanbin, Dong Yulin. Practice and discussion of case teaching method in medical laboratory practice teaching [J]. International Journal of laboratory medicine, 2016,37 (01): 138-139

8. Novel coronavirus pneumonia, PBL $+\mathrm{CBL}$, Wang Shanshan, Li Jinling. Application of PBL+CBL based on nail platform in the teaching of respiratory system in clinical undergraduate $[\mathrm{J}]$. Chinese higher medical education, 2020 (07): 65-66.

9. Wang Huan, Huang Hai, Wu Heming. Relationship between personality characteristics and mobile phone dependence of college students: mediating role of social anxiety [J]. Chinese Journal of clinical psychology, 2014,22 (03): 447-450

10. Nie Juan. Research on the application of nail in college students' mental health education under the background of epidemic situation $[\mathrm{J}]$. Chinese Journal of multimedia and network teaching (last ten days), 2020 (11): 34-36 